Bull. Chem. Soc. Ethiop. 2021, 35(3), 647-657.

(c) 2021 Chemical Society of Ethiopia and The Authors

ISSN 1011-3924

DOI: https://dx.doi.org/10.4314/bcse.v35i3.15

Printed in Ethiopia

Online ISSN 1726-801X

\title{
RED-SEA DOLOMITE AS A SUSTAINABLE CATALYST IN THE SYNTHESIS OF BIS-INDOLYL METHANES WITH MOLECULAR DOCKING VALIDATION AS HIV-1 REPLICATION INHIBITOR
}

\author{
M. Abdelghany ${ }^{1}$ and Tamer K. Khatab ${ }^{2 *}$ \\ ${ }^{1}$ Spectroscopy Department, Physics Division, National Research Centre, 33 El-Behouth St., \\ Dokki, 12622, Cairo, Egypt \\ ${ }^{2}$ Organometallic-Organometalloid Chemistry Department, Chemical Industries Research \\ Division, National Research Centre, 33 El-Behouth St., Dokki, 12622, Cairo, Egypt
}

(Received June 30, 2021; Revised November 30, 2021; Accepted December 7, 2021)

\begin{abstract}
Dolomite minerals were collected from the Red Sea Mountains around the Sokhna region. The rock was collected, rinsed, and crushed using a ball mailing machine and used without further purification. The dolomite sample was characterized using FTIR, XRD, SEM/EDAX, and mapping to ensure their composition and homogeneity. The obtained data reveal that the presence of a homogenous crystalline structure of $\mathrm{CaMg}\left(\mathrm{CO}_{3}\right)_{2}$. The characterized rock was used as a catalyst in the eco-friendly synthesis of bis-indolyl methane derivatives by reacting two moles of unsubstituted indole and various aromatic aldehydes in the presence of Red-Sea Dolomite mineral as an economical, recyclable, easily obtained, and nontoxic catalyst under solvent-free conditions. The molecular docking study explained that the bis-indolyl methane can be considered as a small molecule stimulator of HIV-1 frameshifting and inhibitor of viral replication.
\end{abstract}

KEY WORDS: Indole, Dolomite, HIV-1, Catalyst, Frameshifting, Viral replication

\section{INTRODUCTION}

Diindolylmethane (DIM) is a natural product formed as an active metabolite when indole-3 carbinol is metabolized inside our body. The common natural sources are cruciferous vegetables such as broccoli, cabbage, Brussel sprouts, cabbage, and kale. All updated research studies established that DIM has a lot of health benefits [1]. The benefits of DIM include promoting a smooth transition to menopause, promoting hormonal balance in people with polycystic ovarian syndrome (PCOS). PCOS women also have hormonal imbalances that cause hirsutism and acne (unwanted growth of hair on the face and body). Research also demonstrates promising DIM antitumor activity towards breast cancer [2]. Also, during the last decade, an enormous number of other biological activities were presented as antiangiogenic [3], antimicrobial [4], antibiotic antimetastatic [5, 6], growth-promoting [7], anti-inflammatory, and analgesic [8]. And so, a few years ago numerous numbers of research groups [9-17] competed for innovating an efficient and facile synthetic method for the synthesis of DIM. Even so, the effectiveness of these catalysts have many drawbacks economically, toxicity, special reaction condition, and long reaction time. DIM synthesis is still in need of a new catalytic reaction that overcomes all drawbacks.

Dolomite is a common rock-forming mineral with the chemical structure $\operatorname{CaMg}\left(\mathrm{CO}_{3}\right)_{2}$. Dolomite is considered a primary component of the sedimentary rock aged about 30 million years. Such mineral has the advantage to be used as a source of magnesia $(\mathrm{MgO})$, a feed additive for livestock, a sintering agent and flux in metal processing, and as an ingredient in the production of glass, bricks, and ceramics. Dolomite is usually used as an acid neutralizer in many industrial, restoration projects, and as a soil conditioner. The goal of the presented study is to implement an environmentally and economically friendly route for catalytic BIM synthesis. As a catalyst, we

*Corresponding author. E-mail: tamer_khatab@hotmail.com

This work is licensed under the Creative Commons Attribution 4.0 International License 
use the Red-Sea Dolomite mineral, which has many benefits. Besides, molecular docking study as HIV-1 Frameshift Site RNA Bound to a Small Molecule Inhibitor of Viral Replication. And this study may consider as one of the starting theoretical points for structure-based optimization of compounds targeting the HIV-1 frameshift site RNA.

\section{EXPERIMENTAL}

Catalyst collection and preparation

Dolomite mineral was collected from the Red Sea Mountains around the Sokhna region in the mid of October 2020. The mineral was crushed using a ball mailing machine and used without further purification. The region was identified by the red arrow in the Gulf of Suez region aged about 30 million years as reported by Bosworth in his review (Figure 1) [18].

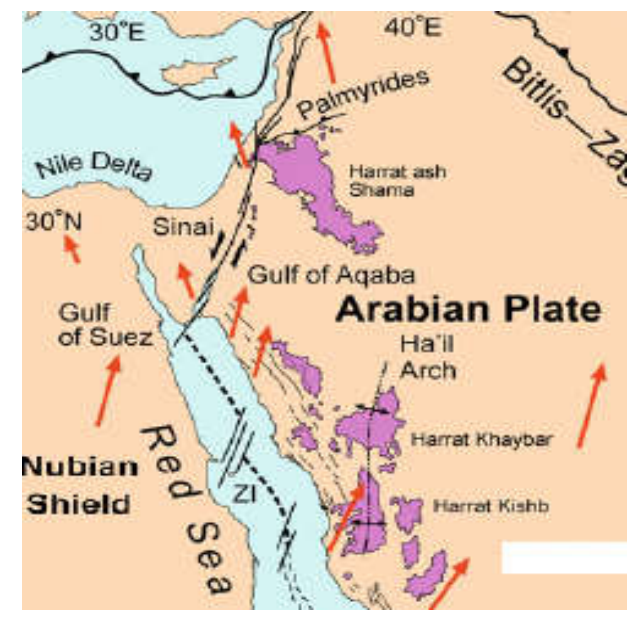

Figure 1. Map of Red Sea Mountains around Sokhna region.

\section{Catalyst characterization}

Studied rock mineral was analyzed via XRD to identify possible present crystalline phases precipitated within the sample and to identify their nature. The studied sample was ground to a fine powder and tested using a Philips PW 1390 X-ray diffractometer adopting Ni-filter and Cutarget operating at $30 \mathrm{kV}$. The obtained pattern was compared with that of dolomite mineral standard JCPDS ASTM card NOS. 5-0586. FTIR absorption spectral data were performed on a powdered sample using $\mathrm{KBr}$ route adopting Nicolet 10 spectrophotometer in the spectral range $4000-400 \mathrm{~cm}^{-1}$. Scanning electron microscopic (SEM) study carried out on powdered sample coated with a thin layer of gold using JSM-7500F field emission microscope supported with EDAX unit using accelerating voltage $30 \mathrm{kV}$, magnification up to $\times 400,000$.

Organic synthesis procedure and structure identification

The aromatic aldehyde $(10 \mathrm{mmol})$ was reacted with $(20 \mathrm{mmol})$ of indole in the presence of mineral rock catalyst $(10 \mathrm{mg})$. The reaction mixture was stirred at $60-70{ }^{\circ} \mathrm{C}$ for the appropriate time. The reaction was checked by using ultraviolet active TLC till all starting material were consumed. The reaction mixture was dissolved in ethyl acetate then filtered and the filtrate was evaporated using 
vacuum rotatory after that the targeted product was obtained. As examples of spectral data 3,3'((5-Nitrofuran-2-yl)methylene)bis(1H-indole) $3 \mathrm{e},(400 \mathrm{MHz}$ for proton NMR and $100 \mathrm{MHz}$ for carbon NMR) $\delta=8.08-6.40(\mathrm{~m}, 14 \mathrm{H}, 2 \mathrm{NH}+12 \mathrm{ArH}), 5.99(\mathrm{~s}, 1 \mathrm{H}) ;{ }^{13} \mathrm{C}-\mathrm{NMR} \delta=179-115(20$ C), $34(1 \mathrm{C}) \mathrm{ppm}$. IR (KBr): $v=3404(\mathrm{NH}) \mathrm{cm}^{-1}, \mathrm{MS}(\mathrm{EI})[\mathrm{M}]^{+}=357$.

\section{RESULTS AND DISCUSSION}

\section{XRD experimental data}

$\mathrm{X}$-ray diffraction analysis of the powdered sample and their respective crystal structure is shown in Figure 2. Distinct sharp bands originally located at 23.2, 29.4, 30.1, 36, 39.5, 40.1, 43.1, 44.8, $47.3,48.6,51,57.5,60.7$, and 64.7 degrees were observed and correlated to their corresponding characteristic peaks of dolomite previously reported in JCPDS ASTM card NOS. 5-0586 [19].

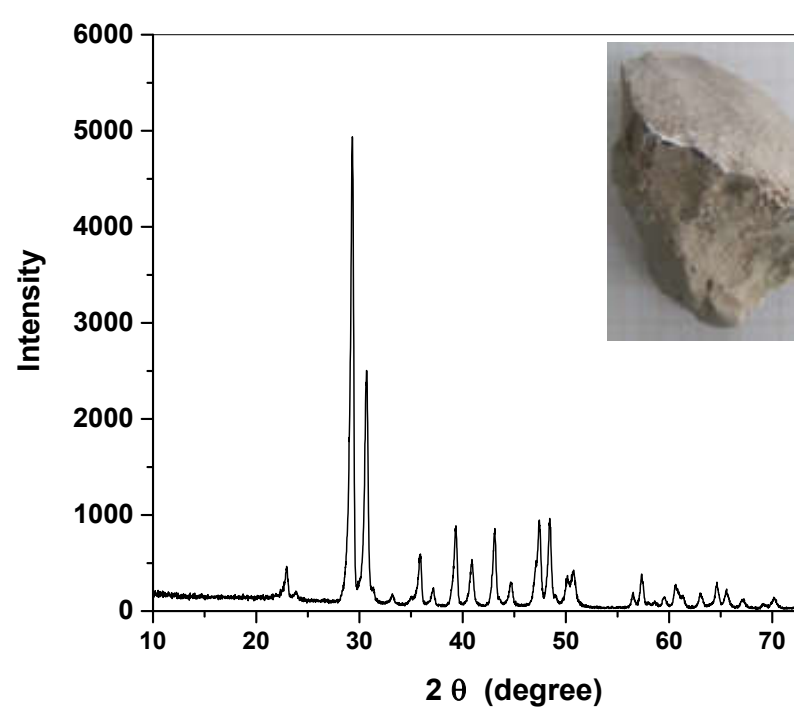

(a)

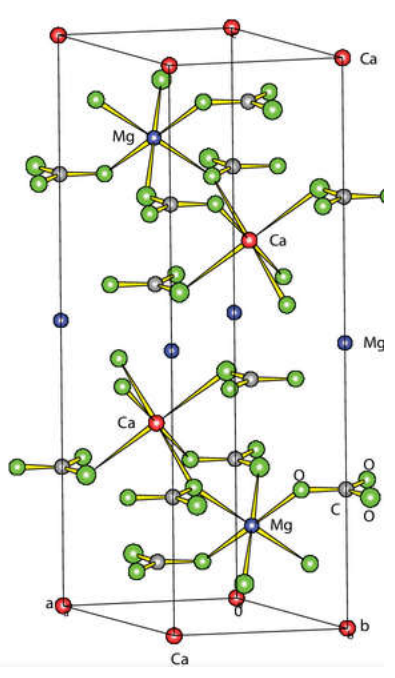

(b)

Figure 2. XRD pattern and crystal structure of dolomite sample.

\section{SEM/EDAX/MAP analysis of studied catalyst}

Figure 3 reveals SEM micrograph supported by EDAX and mapping. Obtained data reveals the crystalline nature of the powdered sample and shows the percentage of each component in combination with their homogenous distribution shown from the mapped images. EDX is simply known as energy-dispersive X-ray spectroscopy representing a direct and powerful tool that enables scientists to analyze and identify the chemical composition of studied samples depending on the core electron ejection with high energy X-ray radiation (Moseley's Law) gives a direct correlation between frequency of emitted radiation and the atomic number of the atom.EDX results were represent for the studied sample and showed that the presence of both carbon and oxygen lines originally located at 0.2774 and $0.525 \mathrm{keV}$, respectively, Figure 4 . While both calcium and magnesium are represented by lines originally located at their reported positions (Table 1). 


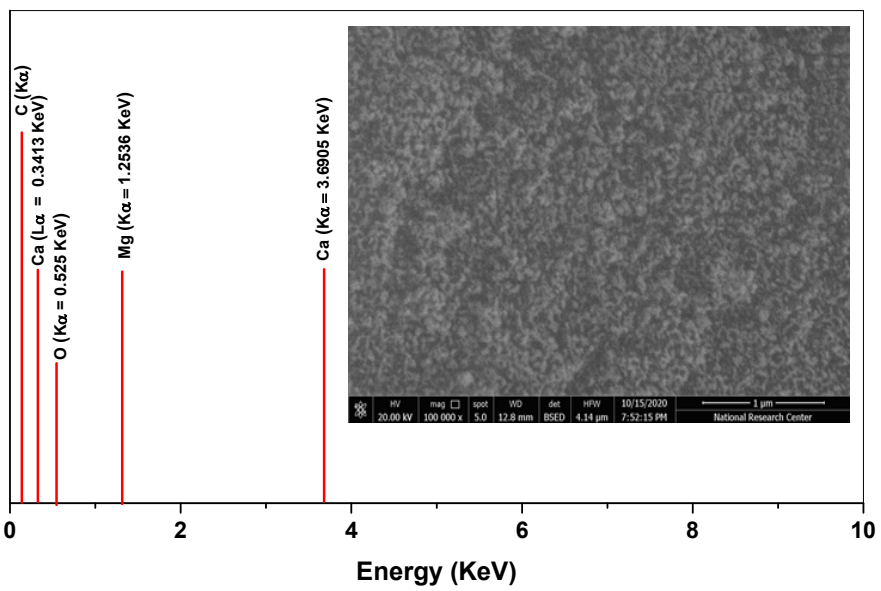

(a)

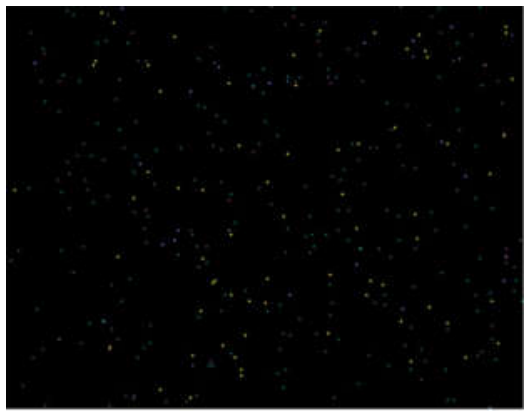

\% O K

$0 \% \quad \mathbf{C ~ K}$

\%\% Mg K

०\% Ca K

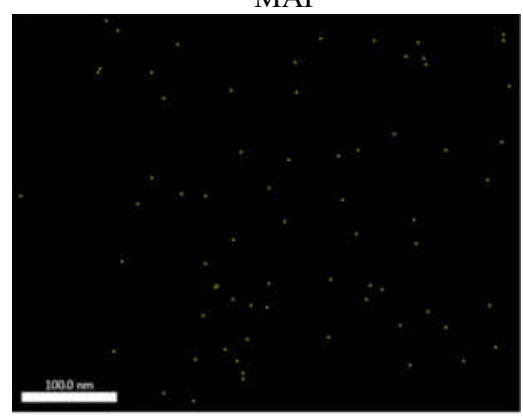

C

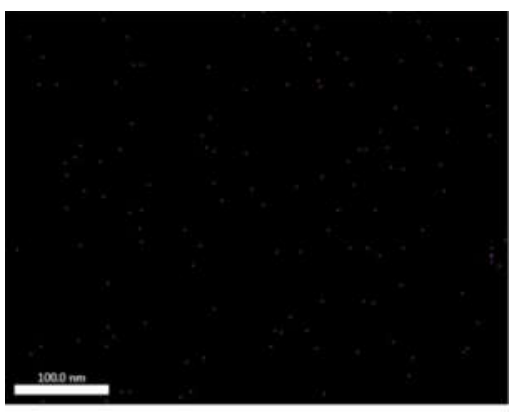

$\mathrm{O}$

Bull. Chem. Soc. Ethiop. 2021, 35(3) 

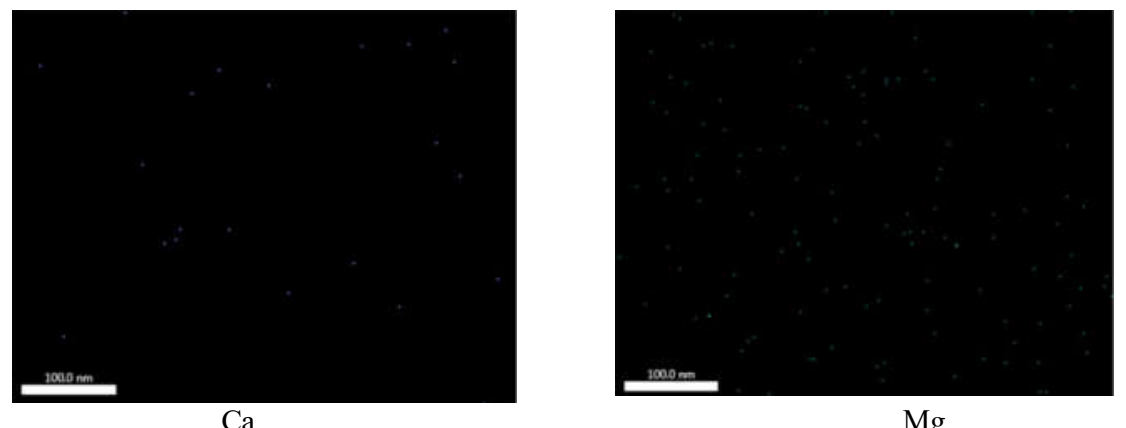

(b)

Figure 3. EDX analysis of the studied sample with their mapping.

Table 1. EDX energies of the studied sample components.

\begin{tabular}{|l|l|l|}
\hline Element & Transition & Energy $(\mathrm{keV})$ \\
\hline \multirow{2}{*}{$\mathrm{Ca}$} & $(\mathrm{k} \alpha)$ & 3.6905 \\
\cline { 2 - 3 } & $(\mathrm{L} \alpha)$ & 0.3413 \\
\hline $\mathrm{Mg}$ & $(\mathrm{k} \beta)$ & 1.2536 \\
\hline $\mathrm{O}$ & $(\mathrm{k} \alpha)$ & 0.525 \\
\hline $\mathrm{C}$ & $(\mathrm{k} \alpha)$ & 0.2774 \\
\hline
\end{tabular}

Fourier transform infrared (FTIR)

Pure dolomite reported to be formed by $\left.\mathrm{MgCaCO}_{3}\right)_{2}$, the carbonates in the studied sample was characterized through demonstrated the strong band at $2870,2515,1795,1425,710 \mathrm{~cm}^{-1}$ as shown in Figure 4.

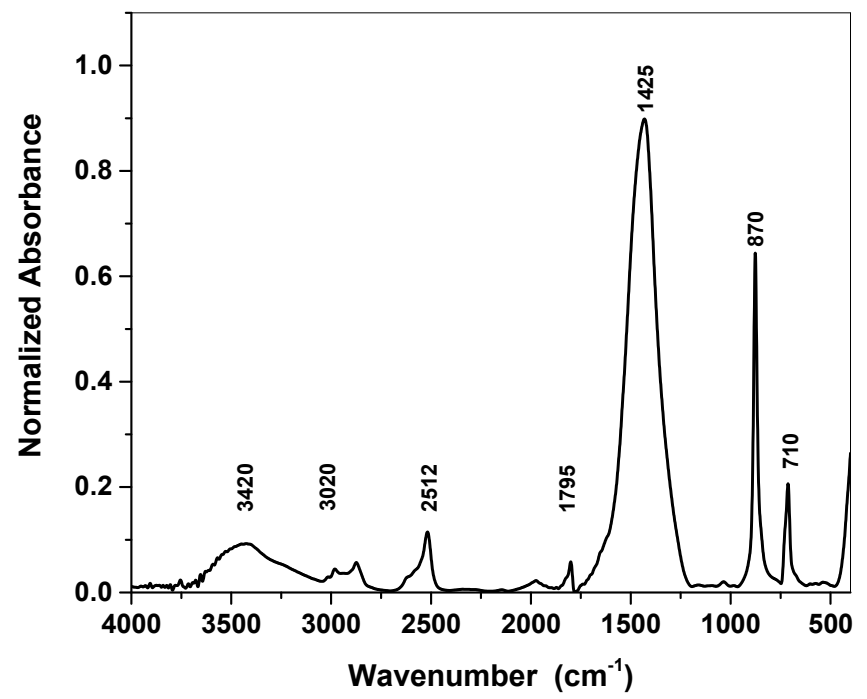

Figure 4. FTIR spectral data for catalyst and material used for preparation. 
Organic reaction

The phenomenon of applying catalysis in the organic reaction is endlessly fascinating and perennially new. Our research group all time looking for discovering new catalysts and make their characterization then using them in organic synthesis development [20-28]. Herein we presented a new category of catalyst used to synthesis the significant class of organic compounds (BIM). Two moles of indole $(1.17 \mathrm{~g}, 10 \mathrm{mmol})$ mixed with one mole of benzaldehyde $(0.5 \mathrm{~mL}, 5 \mathrm{mmol})$ in the presence of Red-Sea Dolomite $(10 \mathrm{mg}$ ) catalyst under solvent-free conditions (Scheme 1). The reaction was optimized by comparing the presented catalyst "Red-Sea Dolomite catalyst" with other diverse known catalysts. The data obtained showing that the Red-Sea Dolomite catalyst gives better yield and less reaction time (Table 2).

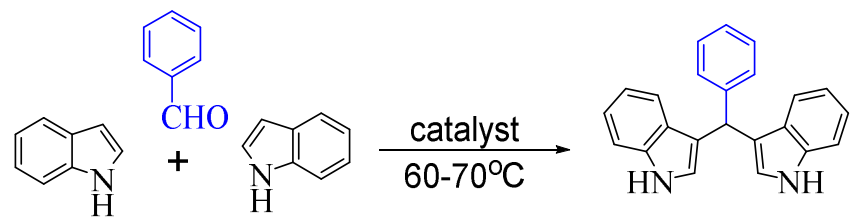

Scheme 1. Synthesis of model example of BIMs.

Table 2. Reaction optimization.

\begin{tabular}{|c|c|c|c|}
\hline Entry & Catalyst & Time & Yield \\
\hline 1 & Red-Sea Dolomite catalyst & $10 \mathrm{~min}$ & 90 \\
\hline 2 & $\mathrm{Silica}$ & $3.5 \mathrm{~h}$ & 70 \\
\hline 3 & $\mathrm{ZnCl}_{2} / \mathrm{SiO}_{2}$ & $54 \mathrm{~min}$ & 60 \\
\hline 4 & $\mathrm{~V}_{2} \mathrm{O}_{5} / \mathrm{SiO}_{2}$ & $3 \mathrm{~h}$ & 80 \\
\hline 5 & $\mathrm{Sm}_{2} \mathrm{O}_{3} / \mathrm{SiO}_{2}$ & $20 \mathrm{~min}$ & 85 \\
\hline
\end{tabular}

In Scheme 2, the proposed mechanism for the catalyzed synthesis of bisindolylmenthane (II) by the Rock catalyst was discussed. The $\mathrm{C}=\mathrm{O}$ polarization in the aldehydic group was stimulated by the characterized Red-Sea Dolomite catalyst, the highly polar carbonyl motivates the nucleophilic attack from $\beta$-indole position and after dehydration formed intermediate (I). The second mole of indole was added to the activated form of $\mathbf{I}$ forming the final product BIM.

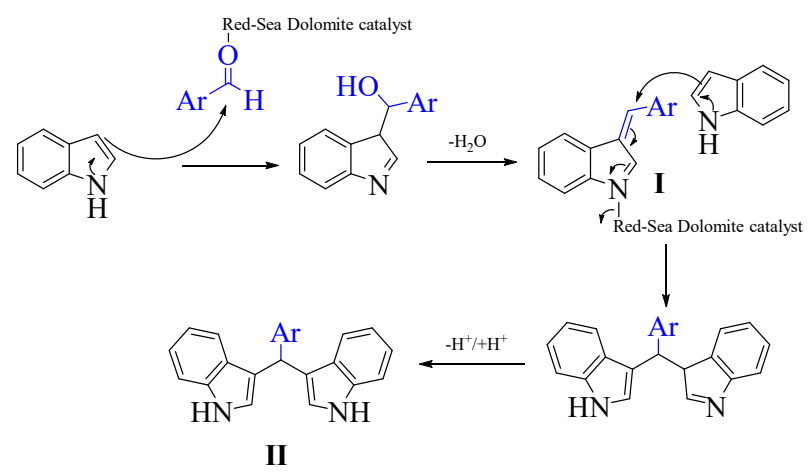

Scheme 2. The proposed reaction mechanism.

Bull. Chem. Soc. Ethiop. 2021, 35(3) 
To clarify the potential of this catalytic reaction for the preparation of BIMs, the reaction was extended by aromatic aldehydes derivatives and the data obtained were summarized in (Table 3 and Scheme 3).

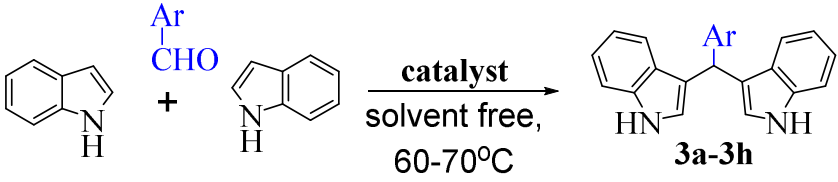

Scheme 3. Synthesis of BIMs.

Table 3. Synthesis of BIMs using various aldehydes.

\begin{tabular}{|l|l|c|c|c|c|c|}
\hline & Ar & Product & Yield (\%) & $\begin{array}{c}\text { M.p. }\left({ }^{\circ} \mathrm{C}\right) \\
\text { Found/reported }\end{array}$ & $\begin{array}{c}\text { Time } \\
(\mathrm{min})\end{array}$ & Ref. \\
\hline 1 & Phenyl & $\mathbf{3 a}$ & 85 & $145 / 149-150$ & 10 & {$[30]$} \\
\hline 2 & $p$-Nitrophenyl & $\mathbf{3 b}$ & 80 & $210 / 217-220$ & 5 & {$[30]$} \\
\hline 3 & $p$-Chlorophenyl & $\mathbf{3 c}$ & 95 & $73 / 76-77$ & 6 & {$[31]$} \\
\hline 4 & $m$-Tolyl & $\mathbf{3 d}$ & 80 & $90 / 98-99$ & 15 & {$[32]$} \\
\hline 6 & 5-Nitrofurfuryl & $\mathbf{3 e}$ & 90 & 83 & 10 & {$[33]$} \\
\hline 7 & $p$-Fluorophenyl & $\mathbf{3 f}$ & 70 & $78 / 80-82$ & 4 & {$[34]$} \\
\hline 8 & $m$-Chlorophenyl & $\mathbf{3 g}$ & 70 & $83 / 83-85$ & 5 & {$[35]$} \\
\hline 9 & $o$-Chlorophenyl & $\mathbf{3 h}$ & 95 & $105 / 108-109$ & 4 & {$[36]$} \\
\hline
\end{tabular}

*Melting points are uncorrected.

The data in Table 3 described that the aromatic aldehyde substituted by electron withdrawing groups like $\left(\mathrm{NO}_{2}, \mathrm{Cl}, \mathrm{F}\right)$ requires less reaction times and give high yields. And the aromatic aldehydes substituted by electron releasing groups need long reaction times and give low yields.

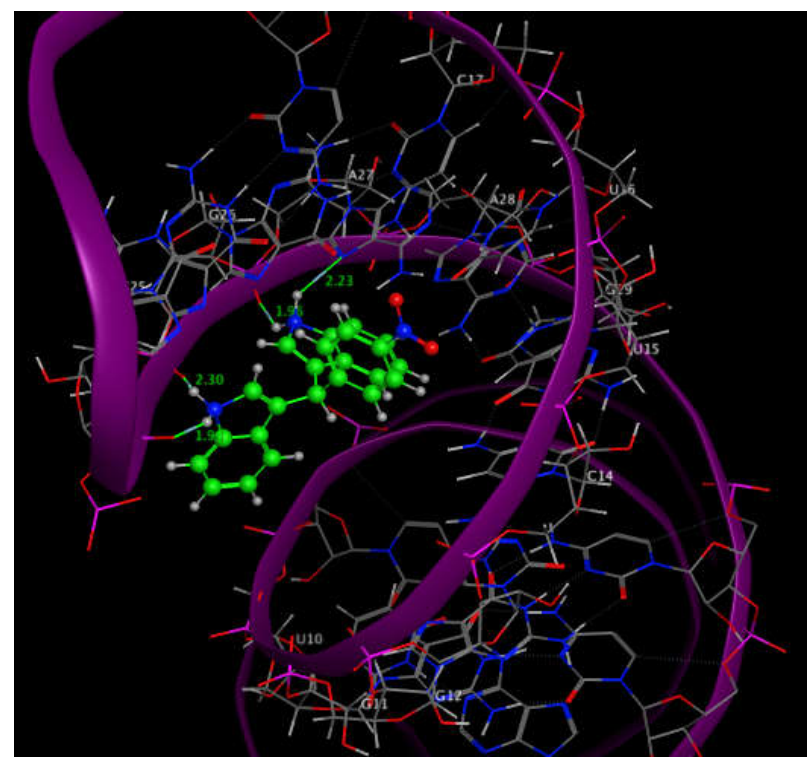

Figure 5. 3D structure of $\mathbf{3 b}$ with HIV-1 frameshift site RNA.

Bull. Chem. Soc. Ethiop. 2021, 35(3) 
Molecular docking study

More than a quarter-century after its initial detection human immunodeficiency virus (HIV), the primary cause fiction, of AIDS, continues to be a major health concern. The latest figures suggest 33 million people infected worldwide with HIV, with more than 25 million have died as a result of complications resulting from AIDS [37]. The affinity and efficacy of the drug can be expected using Molecular docking software (Figure 5), explains the interaction between HIV-1 RNA and prepared compound $\mathbf{3 b}$.

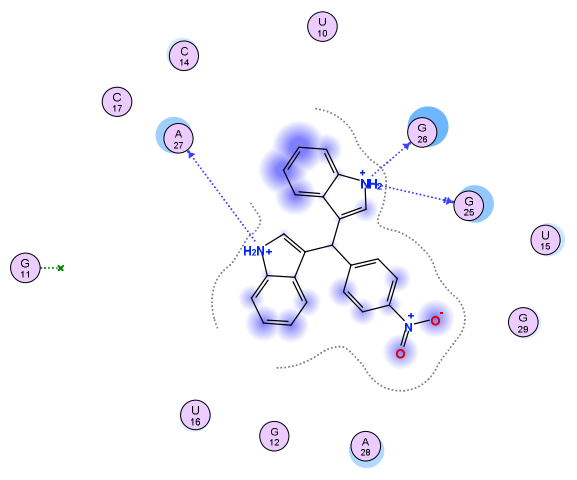

Figure 6. 2D structure for $3 \mathrm{~b}$ and HIV-1 frameshift site RNA.

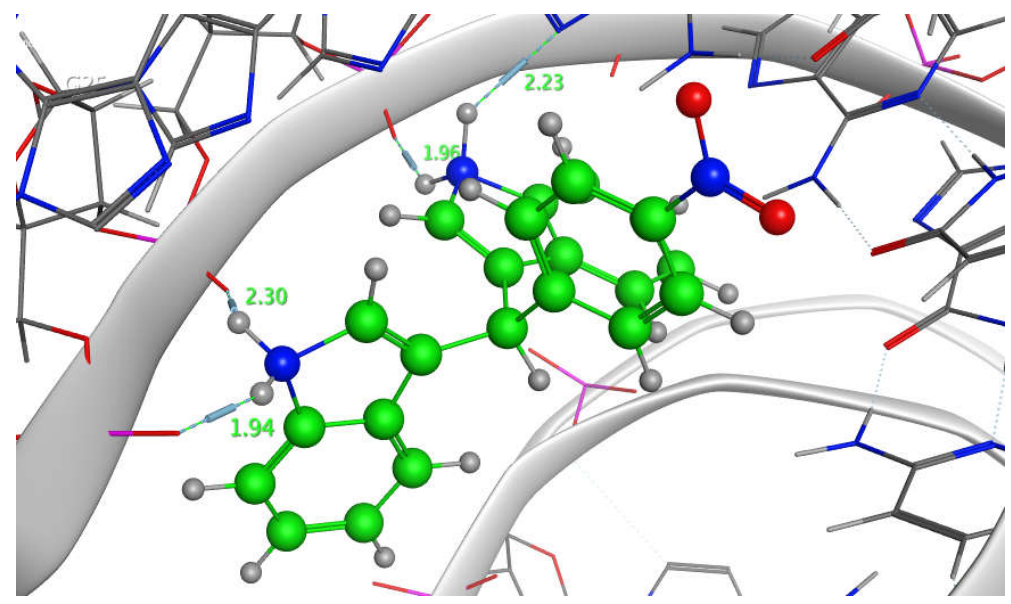

Figure 7. The 3D structure of bond length between $\mathbf{3 b}$ and HIV-1 frameshift site RNA.

The energy score in $\mathrm{kcal} / \mathrm{mol}$ (E-score) calculation reflects the primary information for the binding process between the ligand and enzyme. The validation calculation of E-score between bis[N-(3-dimethylaminopropyl)amidino]benzene tetrahydrochloride (DB213) as reference ligand molecules [38] and the bisindolylmetahnes $\mathbf{3 a - 3 h}$ in the cationic form as prepared ligands $\mathbf{3 a - 3 \mathbf { h }}$. The compounds targeting the HIV-1 frameshift site RNA (the viral RNA in PDB format downloaded from PDB website cod number 2194). The E-score for reference ligand is -6.38 and 
for the prepared ligand are $-5.92,-6.61,5.98,-6.03,-5.87,-5.65,-5.60$ and $-6.09 \mathrm{kcal} / \mathrm{mol}$, respectively. Figure 6 showed the 2D interaction diagrams for drug ligand interaction with HIV1 frameshift site RNA.

The bond distance also can consider an important factor and help in interpreted the type of interaction between ligand and targeted biomolecules the following Figure 7 explained that the RNA residues Adenine 27, Guanine 25, and Guanine 26 linked with compound $\mathbf{3 b}$ with bond angle $2.23,1.98,2.30$ and $1.94 \AA$.

\section{CONCLUSIONS}

Dolomite mineral was collected from the Red Sea Mountains around the Sokhna region and then it was successfully used as a catalyst in the synthesis of Bis-indolyl methane derivatives after ensuring their structure and composition. The studied catalyst was approved to be consist of crystalline homogenous magnesium carbonate mineral. Bis-indolyl methane derivatives were prepared using the characterized catalysis. And this catalytic reaction was a proved to be an efficient, green, and facile catalyst organic reaction. In addition, the molecular docking study explained that the bis-indolyl methane can be considered as a small molecule stimulator of HIV1 frameshifting and inhibitor of viral replication.

\section{REFERENCES}

1. Diindolylmethane: Overview, Uses, Side Effects. Available at: https://www.webmd.com/vitamins/ai/ingredientmono-1049/diindolylmethane.

2. Hong, C.; Firestone, G.L.; Bjeldanes, L.F. Bcl-2 family-mediated apoptotic effects of 3,3'diindolylmethane (DIM) in human breast cancer cells. Biochem. Pharmacol. 2002, 15, 10851097.

3. Kobayashi, M.; Aoki, S.; Gato, K.; Matsunami, K.; Kurosu, M.; Kitagawa, I. Marine natural products. XXXIV. Trisindoline, a new antibiotic indole trimer, produced by a bacterium of Vibrio sp. separated from the marine sponge Hyrtiosaltum. Chem. Pharm. Bull. 1994, 42, 2449-2451.

4. Sivaprasad, G.; Perumal, P.T.; Prabavathy, V.R.; Mathivanan, N. Synthesis and anti-microbial activity of pyrazolylbisindoles - promising anti-fungal compounds. Bioorg. Med. Chem. Lett. 2006, 16, 6302-6305.

5. Giannini, G.; Marzi, M.; Tinti, M.O.; Pisano, C. International patent. WO0236597; Chem. Abstr. 2000, 136, 355230.

6. Khan, K.M.; Rahim F. Wedd, A.; Taha M. Khan, M.; Naurin, S.; Chowdhury, M.I. Biomed. Biochem. Lett. 2014, 24, 1825-1829; Valeria, L.; Ernesto, M.; Ambrogio, O.; Frank, G.; HansWilli, K. 2000, EP0991645.

7. Pal, C.; Dey, S.; Mahato, S.K.; Vinayagam, J.; Pradhan, P.K.; Giri, V.S.; Biswas, S.M. Ecofriendly synthesis and study of new plant growth promoters: 3,3'-Diindolylmethane and its derivatives, Bioorg. Med. Chem. Lett. 2007, 17, 4924-4928.

8. Sujatha, K.; Perumal, P.T.; Muralidharan, D.; Rajendran, M. Synthesis, analgesic and antiinflammatory activities of bis (indolyl) methanes. Indian J. Chem. 2009, 48(B), 267-272.

9. Hasaninejad, A.; Shekouhy, M.; Zare, A.; Ghattali, S.M.S.H.; Golzar, N. PEG-SO ${ }_{3} \mathrm{H}$ as a new, highly efficient and homogeneous polymeric catalyst for the synthesis of bis (indolyl) methanes and 4,4'-(arylmethylene)-bis (3-methyl-1-phenyl-1H-pyrazol-5-ol)s in water. $J$. Iran. Chem. Soc. 2011, 8, 411-423.

10. Khaksar, S.; Ostad, S.M. Pentafluorophenylammonium triflate as an efficient, environmentally friendly and novel organocatalyst for synthesis of bis-indolyl methane derivatives. J. Fluorine Chem. 2011, 132, 937-939. 
11. Kolvari, E.; Zolfigol, M.A.; Banary, H. Surfactant-assisted synthesis of bis (indolyl) methanes in water, Chin. Chem. Lett. 2011, 22, 1305-1308.

12. Qu, H.E.; Xiao, C.; Wang, N.; Yu, K.H.; Hu, Q.S.; Liu, L.X. $\mathrm{RuCl}_{3} \cdot 3 \mathrm{H}_{2} \mathrm{O}$ catalyzed reactions: Facile synthesis of bis (indolyl) methanes under mild conditions. Molecules 2011, 16, 38553868.

13. Kamble, S.; Rashinkar, G.; Kumbhar, A.; Salunkhe, R. Hydrotrope induced catalysis in water: a clean and green approach for the synthesis of medicinally relevant bis (indolyl) methanes and 2-aryl benzimidazoles, Synth. Commun. 2012, 42, 756-766.

14. Yadav, J.S.; Reddy, B.V.S.; Murthy, C.V.S.R.; Kumar, G.M.; Madan, C. Lithium perchlorate catalyzed reactions of indoles: An expeditious synthesis of bis (indolyl) methanes, Synthesis 2001, 5, 783-787.

15. Ramesh, C.; Banerjee, J.; Pal, R.; Das, B. Silica supported sodium hydrogen sulfate and amberlyst-15: Two efficient heterogeneous catalysts for facile synthesis of bis-and tris $(1 \mathrm{H}-$ indol-3-yl) methanes from Indoles and carbonyl compounds. Adv. Synth. Catal. 2003, 345, 557-559.

16. Chakrabarty, M.; Ghosh, N.; Basak, R.; Harigaya, Y. Dry reaction of indoles with carbonyl compounds on montmorillonite K10 clay: A mild, expedient synthesis of diindolylalkanes and vibrindole A. Tetrahedron Lett. 2002, 43, 4075-4078.

17. Seyedi, N.; Khabazzadeh, H.; Saidi, K. $\mathrm{Cu}_{1.5} \mathrm{PMo}_{12} \mathrm{O}_{40}$ as an efficient, mild and heterogeneous catalyst for the condensation of indole with carbonyl compounds. Mol. Divers. 2009, 13, 337 342.

18. Bosworth, W. Geological evolution of the Red Sea: Historical Background, Review, and Synthesis in The Red Sea, Springer: Berlin; 2015, pp 45-78.

19. Shamsuddin, M.R.; Asikin-Mijan, N.; Marliza, T.S.; Miyamoto, M.; Uemiya, S.; Yarmo, M.A.; Taufiq-Yap, Y.H. Promoting dry reforming of methane via bifunctional NiO/dolomite catalysts for production of hydrogen-rich syngas. RSC Adv. 2021, 11, 6667-6681.

20. Khatab, T.K. An efficient catalytic synthesis of 1,8-dioxo-octahydroxanthene derivatives with anti-oxidant scanning. Egypt. J. Chem. 2018, 61, 661-666.

21. Khatab, T.K.; Elmorsy, S.S.; Badawy, D.S. Evaluation of $\mathrm{TCS} / \mathrm{ZnCl}_{2}$ with acetic anhydride as an acetylating reagent for methylene ketones. Phosphorus, Sulfur, Silicon 2005, 180, 109116.

22. Khatab, T.K.; Hassan, A.S.; Hafez, T.S. $\mathrm{V}_{2} \mathrm{O}_{5} / \mathrm{SiO}_{2}$ as an efficient catalyst in the synthesis of 5-aminopyrazole derivatives under solvent free condition. Bull. Chem. Soc. Ethiop. 2019, 33, 135-142.

23. Naglah, A.M.; Askar, A.A.; Hassan, A.S.; Khatab, T.K.; Al-Omar, M.A.; Bhat, M.A. Biological evaluation and molecular docking with in silico physicochemical, pharmacokinetic and toxicity prediction of pyrazolo [1,5-a] pyrimidines. Molecules 2020, 25, 1431.

24. Khatab, T.K.; Mubarak, A.Y.; Hanan, A.S. Design and synthesis pairing between xanthene and tetrazole in pentacyclic system using tetrachlorosilane with aurora kinase inhibitor validation. J. Heterocycl. Chem. 2017, 54, 2463-2470.

25. Soliman, H.A.; Khatab, T.K.; Abdel-Megeid, FME. Utilization of bromine azide to access vicinal-azidobromides from arylidene malononitrile. Chin. Chem. Lett. 2016, 27, 1515-1518.

26. Badawy, D.S.; Abdel-Galil, E.; Kandeel, E.M.; Basyouni, W.M.; Khatab, T.K. Tetrachlorosilane-zinc chloride as a new potent binary reagent for one-pot, three-component synthesis of Mannich-type products. Phosphorus, Sulfur, Silicon 2009, 184, 2799-2812.

27. Khatab, T.K.; Abdelghany, A.M.; Kandil, E.M.; Elsefy, D.E.; El-Mekabaty, A. Hydroxyapatite/ $/ \mathrm{ZnCl}_{2}$ nano-flakes: An efficient catalyst for the synthesis of 2arylbenzothiazoles with molecular docking and anti-oxidant evaluation, Biointerf. Res. Appl. Chem. 2020, 10, 5182-5187. 
28. Khatab, T.K.; Abdelghany, A.M.; Soliman, H.A. $\mathrm{V}_{2} \mathrm{O}_{5}$ based quadruple nano-perovskite as a new catalyst for the synthesis of bis and tetrakis heterocyclic compounds. Appl. Organometal. Chem. 2019, 33, e4783.

29. Hassan, A.S.; Abdelghany, A.M.; Khatab, T.K. Copper based glass-ceramic as an efficient catalyst in the synthesis of pyrazolo[1,5-a]pyrimidine derivatives under solvent free conditionwith docking validation as COVID-19 main protease $\left(\mathrm{M}^{\mathrm{pro}}\right)$ inhibitor Bull. Chem. Soc. Ethiop. 2021, 35, 185-196.

30. Ji, S.-J.; Wang, S.-Y.; Zhang, Y.; Loh, T.-P. Facile synthesis of bis (indolyl) methanes using catalytic amount of iodine at room temperature under solvent-free conditions, Tetrahedron 2004, 60, 2051-2055.

31. Kamal, A.; Qureshi, A.A. Syntheses of some substituted di-indolylmethanes in aqueous medium at room temperature. Tetrahedron 1963, 19, 513-520.

32. Hong-En, Q.; Chen, X.; Ning, W.; Kai-Hui, Y.; Qiao-Sheng, H.; Liang-Xian, L. $\mathrm{RuCl}_{3} \cdot 3 \mathrm{H}_{2} \mathrm{O}$ catalyzed reactions: Facile synthesis of bis (indolyl) methanes under mild conditions, Molecules 2011, 16, 3855-3868.

33. Khatab, T.K.; Abdelghany, A.M.; Shaker Yasmen, N.O., Kandil, E.M. Evaluation of the optical and structural properties of constructed bis-indole derivatives using $\left(\mathrm{Sm}_{2} \mathrm{O}_{3} / \mathrm{SiO}_{2}\right)$ catalyst. Silicon 2018, 10, 2173-2179.

34. Bandgar, B.P.; Patil, A.V.; Kamble, V.T. Fluoroboric acid adsorbed on silica gel catalyzed synthesis of bisindolyl alkanes under mild and solvent-free conditions. Arkivoc 2007, 16, $252-$ 259.

35. Rekha, M.; Manjunath, H.R.; Nagaraju, N. Mn/ $/ \mathrm{Al}_{2} \mathrm{O}_{3}$ and $\mathrm{Mn} / \mathrm{ZrO}_{2}$ as selective catalysts for the synthesis of bis (indolyl) methanes: The role of surface acidity and particle morphology. J. Ind. Eng. Chem. 2013, 19, 337-346.

36. Azizi, N.; Torkian, L.; Saidi, M.R. Highly efficient synthesis of bis (indolyl) methanes in water. J. Mol. Catal. A: Chem. 2007, 275, 109-112.

37. Ward, D.E. The AmfAR AIDS Handbook: The Complete Guide to Understanding HIV and $A I D S, \mathrm{~W}$. W. Norton \& Co.: New York; 1998.

38. Ryan, J.; Marcheschi, M.; Kumar, A.; Butcher, S.E. Structure of the HIV-1 frameshift site RNA bound to a small molecule inhibitor of viral replication. ACS Chem. Biol. 2011, 6, 857864. 